\title{
Taxonomy and Halotolerance of Mesophilic Methanosarcina Strains, Assignment of Strains to Species, and Synonymy of Methanosarcina mazei and Methanosarcina frisia
}

\author{
GLORIA M. MAESTROJUÁN, ${ }^{1}$ JANE E. BOONE, ${ }^{1}$ ROBERT A. MAH, ${ }^{3}$ JOSÉ A. G. F. MENAIA, ${ }^{1}$ \\ MATTHEW S. SACHS, ${ }^{2}$ AND DAVID R. BOONE ${ }^{1,2 *}$ \\ Department of Environmental Science and Engineering ${ }^{1}$ and Department of Chemical and Biological \\ Sciences, ${ }^{2}$ Oregon Graduate Institute, 19600 N.W. von Neumann Drive, Beaverton, Oregon 97006-1999, \\ and School of Public Health, University of California, Los Angeles, California $90016^{3}$
}

\begin{abstract}
We examined 22 previously described and newly isolated Methanosarcina strains by performing denaturing gel electrophoresis of whole-cell proteins and assigned these strains to previously described species. Methanosarcina mazei $\mathrm{S}^{\mathrm{T}}$ ( $\mathrm{T}=$ type strain) and Methanosarcina frisia $\mathrm{C} 16^{\mathrm{T}}$ were very similar in terms of the electrophoresis patterns of their proteins and in their DNA sequences (the results of reassociation experiments indicated that there was $77 \%$ sequence similarity). Thus, $M$. frisia is a junior subjective synonym of $M$. mazei, and strain $\mathrm{C} 16$ is a reference strain of $M$. mazei. $M$. mazei $\mathrm{C} 16$ was similar to $M$. mazei in other characteristics that have not been reported previously, including the ability to catabolize acetate and a lack of halophily. All of the Methanosarcina strains examined, including the marine strains $M$. mazei $\mathrm{C} 16\left(=M\right.$. frisia $\left.\mathrm{C}^{16}{ }^{\mathrm{T}}\right)$ and Methanosarcina acetivorans $\mathrm{C}^{\mathrm{A}} \mathrm{A}^{\mathrm{T}}$, were slightly halotolerant (rather than halophilic, as originally described). Methanosarcina sp. strain FR-1, which has gas vesicles, was more similar to Methanosarcina barkeri MS $^{\mathbf{T}}$ than to Methanosarcina vacuolata Z-761 ${ }^{\mathrm{T}}$ in both its protein patterns and its DNA sequence (80\% similarity to $M$. barkeri MS ${ }^{\mathrm{T}}$ and $38 \%$ similarity to $M$. vacuolata $Z-761^{\mathrm{T}}$ ). Thus, the presence of gas vesicles is not an adequate taxonomic characteristic for assigning Methanosarcina strains to $M$. vacuolata.
\end{abstract}

The five commonly recognized mesophilic Methanosarcina species (Methanosarcina barkeri, Methanosarcina mazei, Methanosarcina vacuolata, Methanosarcina frisia, and Methanosarcina acetivorans) are found in marine and freshwater environments $(24,33,34)$. The first three of these species are considered to be freshwater species, and their type strains were isolated from freshwater environments. However, early strains of $M$. barkeri were isolated from marine or brackish mud $(36,42)$, and the current type strains of $M$. barkeri and $M$. mazei thrive at marine salinities (40). It has been postulated that Methanosarcina species evolved in marine habitats and adapted to freshwater environments by developing a heteropolysaccharide matrix or capsule (41). When Methanosarcina strains are grown in the presence of marine concentrations of $\mathrm{Na}^{+}$and $\mathrm{Mg}^{2+}$, they have a protein cell wall, are sensitive to lysis by detergents, and occur as individual cells $(35,40,46)$. When these organisms are grown in the presence of low concentrations of these cations, a heteropolysaccharide matrix is often formed, and cells may occur as aggregates, "cysts," or lamina $(27,40,46)$.

The other two mesophilic Methanosarcina species, $M$. frisia and $M$. acetivorans, are considered to be marine species because all of the known strains $\left(M\right.$. frisia $\mathrm{C} 16^{\mathrm{T}}[\mathrm{T}$ $=$ type strain] and $M$. acetivorans $\mathrm{C}^{2} \mathrm{~A}^{\mathrm{T}}$ and $\mathrm{C} 2 \mathrm{E}$ ) were isolated from marine sediments $(4,39)$. The cells of these strains are sensitive to lysis by detergent, and their cell walls are protein $(4,39)$.

In this paper we describe some of the physiological characteristics, especially halotolerance, of some Methanosarcina strains, the results of a phylogenetic analysis, and taxonomic assignments for strains and propose that $M$. maze $i$ and $M$. frisia are synonymous.

\section{MATERIALS AND METHODS}

Source of strains. All of the strains that were not isolated in the course of this study were obtained from the Oregon Collection of Methanogens. The accession numbers and sources of the strains are listed in Table 1.

Media and culture techniques. We used the anaerobic techniques of Hungate (15) with syringes and serum tubes $(27 \mathrm{ml}$, containing $5 \mathrm{ml}$ of medium) or serum vials $(171 \mathrm{ml}$, containing $50 \mathrm{ml}$ of medium, or 2 liters, containing 1 liter of medium) (22). The basal culture medium was MS medium (6), which contained yeast extract, peptones, minerals, coenzyme $M$ and sulfide as reducing agents, and a bicarbonate buffer system. The $\mathrm{pH}$ was 7.2 (with 0.3 atm [30.39 kPa] of $\mathrm{CO}_{2}$ in the headspace) or, for growth of $M$. barkeri $\mathrm{MS}^{\mathrm{T}}$ and $M$. vacuolata $\mathrm{Z}-761^{\mathrm{T}}, 6.7$ (with 1 atm [101.29 kPa] of $\mathrm{CO}_{2}$ in the headspace). The medium was dispensed, the tubes or vials were sealed, and the preparations were sterilized by autoclaving. When $\mathrm{H}_{2}$ was added as a catabolic substrate, it was added by pressurizing the tubes or vials with pure $\mathrm{H}_{2}$ to a level that was $101 \mathrm{kPa}$ above atmospheric pressure after inoculation. These $\mathrm{H}_{2}$-containing cultures were incubated on a shaker and were frequently repressurized (to a level that was $101 \mathrm{kPa}$ above atmospheric pressure) with a mixture of $\mathrm{H}_{2}$ and $\mathrm{CO}_{2}$ (3:1). Other catabolic substrates were added from sterile, anoxic stock solutions (final concentrations, $100 \mathrm{mM}$ methanol, $50 \mathrm{mM}$ acetate, and $15 \mathrm{mM}$ trimethylamine). Media containing various $\mathrm{Na}^{+}$ concentrations were prepared by adding $\mathrm{NaCl}$ to the medium during preparation or by adding a sterile, anoxic stock solution of $\mathrm{NaCl}$ to the prepared medium. MS mineral medium was the same as MS medium except that yeast extract, Trypticase peptones, and coenzyme $\mathbf{M}$ were omitted.

Enrichment and isolation of new Methanosarcina strains. We isolated new Methanosarcina strains from laboratory

\footnotetext{
* Corresponding author.
} 
TABLE 1. Sources and taxonomy of Methanosarcina strains

\begin{tabular}{|c|c|c|c|c|c|c|c|}
\hline \multirow{2}{*}{ Strain } & \multicolumn{2}{|c|}{ Previous taxonomic designation } & \multirow{2}{*}{$\begin{array}{l}\text { Proposed change in } \\
\text { species designation }\end{array}$} & \multicolumn{3}{|c|}{ Other designations $^{a}$} & \multirow{2}{*}{$\begin{array}{l}\text { Reference(s) in which } \\
\text { isolation was } \\
\text { described }\end{array}$} \\
\hline & Taxon & Reference(s) & & $\begin{array}{c}\text { OCM } \\
\text { no. }\end{array}$ & $\begin{array}{l}\text { DSM } \\
\text { no. }\end{array}$ & $\begin{array}{l}\text { ATCC } \\
\text { no. }\end{array}$ & \\
\hline$S-6^{T}$ & M. mazei $^{b}$ & 25 & & $26^{\mathrm{T}}$ & $2053^{T}$ & $43572^{\mathrm{T}}$ & 23 \\
\hline LYC & M. mazei & 19 & & 34 & 4556 & 43573 & 19 \\
\hline $\mathrm{KCl}-2 \mathrm{~S}$ & M. mazei & 14 & & 25 & & & 14 \\
\hline $\mathbf{M S}^{\mathrm{T}}$ & M. barkeri & 9 & & $38^{\mathrm{T}}$ & $800^{\mathrm{T}}$ & $43569^{\mathrm{T}}$ & 9 \\
\hline UBS & M. barkeri & 45 & M. mazei & 27 & 1311 & & 10 \\
\hline 227 & M. barkeri & 2 & & 35 & 1538 & 43241 & 26 \\
\hline $227 \mathrm{BM}^{c}$ & M. barkeri & & & 40 & & & 37 \\
\hline 227BES ${ }^{\text {Ic }}$ & M. barkeri & & & 29 & & & 37 \\
\hline Jülich & M. barkeri & 35 & & 86 & 2948 & & 35 \\
\hline \multirow[t]{2}{*}{ FR-1 } & M. barkeri & 1 & M. barkeri & 93 & 2256 & & 1 \\
\hline & M. vacuolata & 49 & & & & & \\
\hline Fusaro & M. barkeri & 17 & & 83 & 804 & 29787 & 17 \\
\hline S-3 & M. barkeri & 38 & & 37 & & & 38 \\
\hline 3 & M. barkeri & 17 & & 84 & 805 & 29786 & 17 \\
\hline Wiesmoor & M. barkeri & 35 & & 89 & & & 35 \\
\hline $\mathrm{Z}-761^{\mathrm{T}}$ & M. vacuolata & 49,50 & & $85^{\mathrm{T}}$ & $1232^{\mathrm{T}}$ & & 47,49 \\
\hline $\mathrm{C} 2 \mathrm{~A}^{\mathrm{T}}$ & M. acetivorans & 39 & & $95^{\mathrm{T}}$ & $2834^{\mathrm{T}}$ & $35395^{\mathrm{T}}$ & 39 \\
\hline $\mathrm{C} 16^{\mathrm{T}}$ & M. frisia ${ }^{d}$ & 3 & M. mazei & $98^{\mathrm{T}}$ & $3318^{\mathrm{T}}$ & $43340^{\mathrm{T}}$ & 4 \\
\hline \multirow[t]{2}{*}{ Z-558 (= biotype 3 ) } & M. mazei & 12 & M. mazei & 92 & 2244 & & 48 \\
\hline & Methanosarcina sp. & 13 & & & & & \\
\hline CW3A & Methanosarcina sp. & 30 & M. mazei & 20 & & & 28 \\
\hline G1 & Methanosarcina sp. & 12 & M. mazei & 87 & 338 & & \\
\hline Gö1 & Methanosarcina sp. & 12 & M. mazei & 88 & 3647 & & 11 \\
\hline MCMB703 & Methanosarcina sp. & 30 & M. mazei & 213 & & & 32 \\
\hline $\mathrm{GA}^{e}$ & Methanosarcina sp. & 30 & M. mazei & 75 & & & This study \\
\hline $\mathrm{GA} 4^{e}$ & Methanosarcina sp. & 30 & M. mazei & 76 & & & This study \\
\hline $\mathrm{GAS}^{e}$ & Methanosarcina sp. & 30 & M. mazei & 77 & & & This study \\
\hline $\mathrm{GA}^{e}$ & Methanosarcina sp. & 30 & M. mazei & 78 & & & This study \\
\hline GA $8^{e}$ & Methanosarcina sp. & 30 & M. mazei & 79 & & & This study \\
\hline $\mathrm{GA} 12^{e}$ & Methanosarcina sp. & 30 & M. mazei & 80 & & & This study \\
\hline $\mathrm{GA14}^{e}$ & Methanosarcina sp. & 30 & M. mazei & 53 & & & This study \\
\hline $\mathrm{GAl}^{e}$ & Methanosarcina sp. & 30 & M. mazei & 81 & & & This study \\
\hline Equif & Methanosarcina sp. & 30 & M. mazei & 61 & & & This study \\
\hline
\end{tabular}

a OCM, Oregon Collection of Methanogens, Beaverton; DSM, Deutsche Sammlung von Mikroorganismen, Braunschweig, Germany; ATCC, American Type Culture Collection, Rockville, Md.

b Previously Methanococcus mazei (23).

$c$ Mutant of strain 227 (also M. barkeri).

${ }^{d}$ Previously Methanococcus frisius (4).

$e$ Isolated from one of four laboratory scale methanogenic reactors.

$f$ Isolated from the cecum of a horse.

scale anaerobic digestors that were degrading a mixture of short-chain fatty acids (originally inoculated from a swine lagoon); one strain (strain Equi [= OCM 61]) was isolated from a horse cecum. Samples were collected and were immediately serially diluted in MS enrichment medium (similar to MS medium but with decreased concentrations of organic compounds [22]) supplemented with $100 \mathrm{mM}$ methanol as the substrate. Cultures at the highest dilution which produced methane were selected and maintained by periodic transfers to fresh medium. We obtained axenic cultures by serially diluting the cultures and inoculating them into roll tube medium (MS medium supplemented with $20 \mathrm{~g}$ of purified agar per liter and $100 \mathrm{mM}$ methanol). The incubated cultures formed colonies, and the epifluorescent colonies were removed with modified Pasteur pipets (15). Each colony was dispersed in sterile medium, and the resulting preparations were diluted and reinoculated into roll tube medium. We repeated this procedure until we had a pure culture (as determined by the presence of a single colony type, by the lack of growth in medium without substrate, and by microscopic observation) and then one additional time to ensure purity.
Determination of specific growth rates and organic nutrient requirements. Specific growth rates under various environmental conditions were determined from the specific rates of methane formation (21) by cultures adapted to those conditions, taking into account the methane produced by the inoculum prior to transfer (31). The levels of methane were determined by gas chromatography (21). Requirements for organic nutrients were investigated by cultivating the organisms for at least three transfers $(5 \%, \mathrm{vol} / \mathrm{vol})$ in medium containing a catabolic substrate as the sole organic addition.

Electrophoretic analysis of proteins. Cell pellets were collected by centrifugation at $10,000 \times g$ for $20 \mathrm{~min}$, washed in $30 \mathrm{ml}$ of $1 \%$ (wt/vol) $\mathrm{NaCl}$, and suspended in $10 \mathrm{mM} \mathrm{N}-2-$ hydroxyethylpiperazine- $N^{\prime}$-2-ethanesulfonic acid (HEPES)

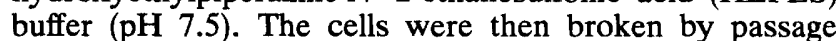
through a French pressure cell $(8,000 \mathrm{kPa})$. Several passages were required to break $M$. barkeri $\mathrm{MS}^{\mathrm{T}}, 227,227 \mathrm{BM}$, 227BES ${ }^{\mathrm{r}}$, Jülich, FR-1, and Fusaro. $M$. vacuolata $\mathrm{Z}-761^{\mathrm{T}}$, which resisted breakage by this method, was broken by suspending $0.1 \mathrm{~g}$ (wet weight) of cells in $0.5 \mathrm{ml}$ of $10 \mathrm{mM}$ HEPES buffer ( $\mathrm{pH} 7.5$ ), adding $0.5 \mathrm{~g}$ of glass beads, and vortexing the preparation four times $(1 \mathrm{~min}$ each). The 
proteins in the lysates were analyzed by using denaturing gel electrophoresis (18).

DNA isolation and reassociation. Cell pellets were collected by centrifugation at $10,000 \times g$ for $20 \mathrm{~min}$ and washed in 30 $\mathrm{ml}$ of a $1 \%(\mathrm{wt} / \mathrm{vol}) \mathrm{NaCl}$ solution. Cells without rigid walls (strains $\mathrm{C} 16^{\mathrm{T}}, \mathrm{S}-6^{\mathrm{T}}$, and $\mathrm{C} 2 \mathrm{~A}^{\mathrm{T}}$ ) were lysed by resuspending them in TE buffer (10 mM Tris, $1 \mathrm{mM}$ EDTA, $0.15 \mathrm{M} \mathrm{NaCl}$; adjusted to $\mathrm{pH} 8$ with $\mathrm{NaOH}$ ) and adding sodium dodecyl sulfate $(0.1 \mathrm{~g} /$ /iter $)$. DNA was harvested from these lysates by using modifications of the chloroform-phenol method (16). Washed cell pellets of other strains were lyophilized and ground with a mortar and pestle (29). This method worked well and yielded high-molecular-weight DNA from Methanosarcina strains which resisted breakage by other methods. This DNA was harvested by using the modifications of Oakley et al. (29) of the technique of Summerton et al. (43), except that we washed the initial DNA pellet with $70 \%$ ( $\mathrm{vol} / \mathrm{vol}$ ) ethanol and extracted carbohydrates after the RNase step with chloroform-isoamyl alcohol (24:1). DNAs for interstrain reassociation experiments were sheared by sonication (16) to lengths of about 200 to 1,500 bases. DNA size was estimated by using agarose gel electrophoresis of denatured DNA and comparison with an HindIII digest of $\lambda$ phage DNA. DNA was labeled by using DNA polymerase (Amersham, Chicago, Ill.), random primers (Amersham), and $\left[\alpha-{ }^{32}\right.$ P]dCTP (NEN Research Products, DuPont, Boston, Mass.). The sizes of some, but not all, of the labeled DNA preparations were determined and were found to be 150 to 800 bases. The concentration of labeled DNA was adjusted to $0.6 \mathrm{mg} / \mathrm{liter}$, and labeled DNA was not used unless its specific activity was at least $10^{11} \mathrm{~Bq} / \mathrm{g}$. The reassociation buffer was $10 \mathrm{mM}$ Tris buffer containing $1 \mathrm{mM}$ EDTA and $0.88 \mathrm{~g}$ of $\mathrm{NaCl}$ per liter ( $\mathrm{pH} 7$ ). Reassociation was done at $61.5^{\circ} \mathrm{C}$ in all experiments; this temperature was $25^{\circ} \mathrm{C}$ below the calculated melting point of the DNA (16). After reassociation (20 to $24 \mathrm{~h}$ ), the remaining single-stranded DNA was digested with S1 nuclease (Pharmacia, Pleasant Hill, Calif.). Undigested DNA was precipitated with trichloroacetic acid and collected on glass fiber filters (16). The reassociation experiments always included four replicates of the negative control (sheared salmon sperm DNA), four replicates of the positive (homologous) control, and three replicates of DNA from each strain that was being tested. All of the relative sequence similarity values were based on reciprocal determinations unless stated otherwise. The standard deviations of the relative sequence similarity values were calculated by using the standard deviations of the radioactive counts for positive controls, negative controls, and sample DNA.

\section{RESULTS}

Isolation and characterization of new Methanosarcina strains. Several new Methanosarcina strains were isolated from four laboratory scale methanogenic reactors, and one strain was isolated from the cecum of a horse (Table 1). These strains grew in MS mineral medium supplemented with methanol as the sole organic substrate. They also grew in MS medium containing acetate, trimethylamine, methanol, or $\mathrm{H}_{2}-\mathrm{CO}_{2}$ as the sole catabolic substrate. These organisms grew in MS medium as individual cells except when they were switched from one substrate to another or after several months of storage without transfer. Under these conditions, aggregates often formed, but these aggregates broke up into individual cells after one or two transfers in
MS medium. All of these strains grew best between $\mathrm{pH} 7.0$ and 7.5 at 37 to $40^{\circ} \mathrm{C}$.

Electrophoretic analysis of Methanosarcina strains. Denaturing polyacrylamide gels of whole-cell proteins have been recognized as valuable taxonomic indicators at the species level (8). Most of the strains that previously have been assigned to the species $M$. barkeri (Table 1) produced protein patterns that were more similar to the protein patterns of $M$. barkeri $\mathrm{MS}^{\mathrm{T}}$ than to the protein patterns of $M$. mazei $\mathrm{S}-6^{\mathrm{T}}, M$. vacuolata $\mathrm{Z}-761^{\mathrm{T}}$, or $M$. acetivorans $\mathrm{C} 2 \mathrm{~A}^{\mathrm{T}}$ (Fig. 1A), supporting the assignment of these strains to $M$. barkeri. An exception was strain UBS, which appeared to be more similar to $M$. mazei S-6 ${ }^{\mathrm{T}}$ than to $M$. barkeri $\mathrm{MS}^{\mathrm{T}}$ (Fig. 1C). The morphology of strain UBS was also similar to the morphology of $M$. mazei $\mathrm{S}-6^{\mathrm{T}}$ because strain UBS usually grew as individual coccoid cells in MS medium and occasionally formed large aggregates. Thus, strain UBS should be considered a reference strain of $M$. mazei. In contrast to previous findings (44), our protein analysis indicated that $M$. barkeri $\mathrm{MS}^{\mathrm{T}}$ and 227 are similar. This similarity is supported by the level of sequence similarity $(97 \%)$ determined by DNA reassociation (41) and by the results of the rRNA cataloging studies of Balch et al. (2), which indicated that these strains are nearly identical.

Strain FR-1 was initially assigned to $M$. barkeri (1). Later, Zhilina and Zavarzin proposed that the possession of gas vesicles by Methanosarcina strains is an exclusive property of the species $M$. vacuolata (49). However, despite the presence of gas vesicles in strain FR-1, the results of an electrophoretic analysis of the whole-cell proteins suggested that this organism should be assigned to $M$. barkeri (Fig. 1A).

All of the Methanosarcina strains that were newly isolated in this study (strains GA3, GA4, GA5, GA6, GA8, GA12, GA14, GA15, and Equi) produced protein patterns that were more similar to those of $M$. mazei S $-6^{\mathrm{T}}$ than to those of $M$. barkeri $\mathrm{MS}^{\mathrm{T}}, M$. vacuolata $\mathrm{Z}-761^{\mathrm{T}}$, or $M$. acetivorans $\mathrm{C} 2 \mathrm{~A}^{\mathrm{T}}$ (Fig. 1B). Thus, these new strains are reference strains of $M$. mazei.

Our study of whole-cell proteins was initially hampered by incomplete breakage of cells by the French pressure cell, especially incomplete breakage of $M$. vacuolata $\mathrm{Z}-761^{\mathrm{T}}$ cells. Low yields of proteins suggested that cell breakage was not complete, so the proteins obtained may not have been representative. When breakage was incomplete, few protein bands were observed, and those bands which did appear were at low molecular weights and were not sharp. Another electrophoretic analysis (44) which relied on breakage by a French pressure cell revealed profound differences between $M$. vacuolata $\mathrm{Z}-761^{\mathrm{T}}$ and other Methanosarcina strains; these results also may have been due to incomplete breakage of $M$. vacuolata cells. When we broke $M$. vacuolata $\mathrm{Z}-761^{\mathrm{T}}$ cells by vortexing them with glass beads, the extracted proteins appeared to be more similar to the proteins of $M$. barkeri $\mathbf{M S}^{\mathrm{T}}$, although some differences remained (Fig. 1).

The results of our protein analysis (Fig. 1C) also suggested that $M$. frisia $\mathrm{C} 16^{\mathrm{T}}$ is similar to $M$. mazei $\mathrm{S}-6^{\mathrm{T}}$.

DNA reassociation of Methanosarcina sp. strain FR-1 with $M$. barkeri $\mathrm{MS}^{\mathrm{T}}$ and $M$. vacuolata $Z-761^{\mathrm{T}}$. To confirm that strain FR-1 is more closely related to $M$. barkeri than to $M$. vacuolata, we labeled the DNA of strain FR-1 and hybridized it with DNAs from $M$. barkeri MS $^{\mathrm{T}}, M$. vacuolata $\mathrm{Z}-761^{\mathrm{T}}$, and $M$. mazei $\mathrm{S}-6^{\mathrm{T}}$. The level of sequence similarity between $M$. barkeri FR-1 and $M$. barkeri $\mathrm{MS}^{\mathrm{T}}$ was $80 \%$ $( \pm 7 \%)$, but the levels of sequence similarity between strain 
FR-1 and the type strains of $M$. vacuolata and $M$. mazei were less than $40 \%$. These are the average results of two separate experiments, but reciprocal analyses (with labeled DNAs from $M$. mazei $\mathrm{S}-6^{\mathrm{T}}$ and $M$. barkeri $\mathrm{MS}^{\mathrm{T}}$ ) were not performed.

Reassociation of DNAs from $M$. frisia $\mathrm{C} \mathrm{16}^{\mathrm{T}}, M$. mazei $\mathrm{S}-6^{\mathrm{T}}$, and $M$. acetivorans $\mathbf{C 2 A}^{\mathbf{T}}$. DNA reassociation data indicated that $M$. frisia C $16^{\mathrm{T}}$ exhibited $77 \pm 11 \%$ sequence similarity with $M$. mazei $\mathrm{S}-6^{\mathrm{T}}$ but only $31 \pm 4 \%$ sequence similarity with $M$. acetivorans $\mathrm{C} 2 \mathrm{~A}^{\mathrm{T}}$. The level of sequence similarity between $M$. mazei $\mathrm{S}-6^{\mathrm{T}}$ and $M$. acetivorans $\mathrm{C} 2 \mathrm{~A}^{\mathrm{T}}$ was 26 $\pm 12 \%$. These data support the hypothesis that $M$. acetivorans is a separate Methanosarcina species but suggest that $M$. mazei and $M$. frisia are subjective synonyms.

Effect of salinity on the growth of Methanosarcina strains. A major previously reported physiological difference between $M$. frisia $\mathrm{C} 16^{\mathrm{T}}$ and $M$. mazei $\mathrm{S}-6^{\mathrm{T}}$ is the effect of salinity on growth. $M$. frisia $\mathrm{C} 16^{\mathrm{T}}$ was isolated from a marine source, and this strain has been reported to be slightly halophilic (4). The source of $M$. mazei was an anaerobic digestor (23), and this strain is slightly halotolerant (21). However, a careful comparison of the effects of salinity on the growth of these two strains has not been described previously, so we tested the growth of $M$. frisia $\mathrm{C}^{16^{\mathrm{T}}}$ and found that, like $M$. mazei (21), M. frisia C $16^{\mathrm{T}}$ was slightly halotolerant but not halophilic (Fig. 2A). Furthermore, we found that a wide range of newly isolated strains of $M$. mazei were also slightly halotolerant, growing well at salinities of 0.75 to $1.0 \mathrm{M} \mathrm{Na}^{+}$ (Fig. 2B and C). Likewise, the other marine Methanosarcina species, $M$. acetivorans, was not halophilic but was slightly halotolerant (Fig. 2A); this species grew better in MS medium with a low osmolarity (ca. 220 mosM) than in medium containing marine concentrations of salt.

The two marine isolates, $M$. frisia $\mathrm{C} 16^{\mathrm{T}}$ and $M$. acetivorans $\mathrm{C} 2 \mathrm{~A}^{\mathrm{T}}$, were more halotolerant when they were grown on trimethylamine than when they were grown on methanol (Fig. 2A).

Catabolism of acetate by $M$. frisia $C \mathbf{1 6}^{\mathrm{T}}$. A second major difference between the previously reported characteristics of $M$. frisia $\mathrm{C} 16^{\mathrm{T}}$ and $M$. mazei S-6 ${ }^{\mathrm{T}}$ is the inability of the former strain to catabolize acetate, although some strains of $M$. mazei, such as strain LYC, cannot catabolize acetate. However, $M$. frisia $\mathrm{C} 16^{\mathrm{T}}$ grew in MS medium containing 50 $\mathrm{mM}$ acetate. Like other Methanosarcina strains (7), methanol-grown $M$. frisia $\mathrm{C} 16^{\mathrm{T}}$ had a 2 -month lag before growth began in acetate-containing medium.

\section{DISCUSSION}

Taxonomy of Methanosarcina sp. strain FR-1. On the basis of characteristics other than possession of vesicles, Methanosarcina sp. strain FR-1 might be placed in either $M$. barkeri or $M$. vacuolata. Archer and King (1) considered strain FR-1 and other Methanosarcina strains with vesicles to be members of $M$. barkeri. However, DNA reassociation studies (20) have shown that $M$. barkeri $\mathrm{MS}^{\mathrm{T}}$ and $M$. vacuolata $\mathrm{Z}-761^{\mathrm{T}}$ exhibit only $61 \%$ DNA sequence similarity, suggesting that they should be different species. The results of an antigenic analysis (5) also support the distinction between $M$. barkeri and $M$. vacuolata. Zhilina and Zavarzin proposed that the possession of gas vesicles by Methanosarcina strains is an important characteristic which indicates that the strains should be assigned to the species $M$. vacuolata (49). Although the physiological differences between $M$. barkeri $\mathrm{MS}^{\mathrm{T}}$ and $M$. vacuolata $\mathrm{Z}-761^{\mathrm{T}}$ are limited, one recognized difference is the inability of the latter strain to grow well on $\mathrm{H}_{2}-\mathrm{CO}_{2}$. This organism grows poorly on $\mathrm{H}_{2}-\mathrm{CO}_{2}$ in complex medium and not at all in mineral medium (21). The results of our protein analysis and DNA reassociation studies indicated that strain FR-1 is more similar to $M$. barkeri $\mathrm{MS}^{\mathrm{T}}$ than to $M$. vacuolata $\mathrm{Z}-761^{\mathrm{T}}$, supporting placement of strain FR-1 in $M$. barkeri as suggested by Archer and King. Also, strain FR-1, like $M$. barkeri $\mathrm{MS}^{\mathrm{T}}$ but unlike $M$. vacuolata $\mathrm{Z}-761^{\mathrm{T}}(21)$, grows in mineral medium supplemented with $\mathrm{H}_{2}-\mathrm{CO}_{2}(1)$. Thus, strain FR-1 is a reference strain of $M$. barkeri, and gas vesicles are not a characteristic that occurs exclusively in $M$. vacuolata strains. We propose that the species description of $M$. barkeri should be emended to include strains with gas vesicles.

Rejection of $M$. frisia as a junior subjective synonym of $\boldsymbol{M}$. mazei. $M$. frisia $\mathrm{C} 16^{\mathrm{T}}$ is physiologically similar $M$. mazei S-6 ${ }^{\mathrm{T}}$. Previously, the major reported differences between these two species were (i) that $M$. frisia is slightly halophilic and $M$. mazei is not and (ii) that $M$. frisia cannot catabolize acetate and $M$. mazei usually can. However, under the conditions used in this study, the type strains of these two species were not halophilic but were halotolerant, and they could catabolize acetate. Furthermore, the level of sequence similarity between the DNAs of these two strains was $77 \%$. Thus, $M$. frisia is a subjective synonym of $M$. mazei, and strain C 16 is a reference strain of $M$. mazei.

Halotolerance of Methanosarcina strains. The Methanosarcina strains which we studied, including the two strains that previously have been reported to be halophilic, were not halophilic, but rather were halotolerant. Even the two Methanosarcina strains that were isolated from marine sources (strains C 16 and $\mathrm{C}^{2} \mathrm{~A}^{\mathrm{T}}$ ) grew faster in 220 mosM medium than they did in media which had marine osmolarities (ca. $1,000 \operatorname{mos} \mathrm{M})$. When a low-osmolarity culture medium is inoculated with a higher-osmolarity culture, hypotonic lysis of cells may result. Thus, care should be taken when the effect of salinity on growth is determined by transferring cultures to media with lower osmolarities in small steps.

Use of whole-cell protein electrophoresis in assignment of strains to species. The assignment of reference strains to Methanosarcina species, including our proposed changes (Table 1), produces a taxonomy with significant agreement with the assignments based on the results of electrophoresis of whole-cell proteins (Fig. 1). The resulting assignments are consistent with previous assignments except for (i) strains FR-1 and C 16, for which our assignments were confirmed by the results of DNA reassociation experiments, and (ii) strain UBS (which was previously assigned to $M$. barkeri [45]), for which our assignment was supported by morphological data.

FIG. 1. Denaturing gel electrophoresis of whole-cell proteins of Methanosarcina strains and molecular weight standards. The standards had molecular weights of $180,000,116,000,84,000,58,000,48,500,36,500$, and 26,600. (A) Molecular weight standards, $M$. acetivorans $\mathrm{C} 2 \mathrm{~A}^{\mathrm{T}}$, $M$. vacuolata Z-761 ${ }^{\mathrm{T}}, M$. mazei S-6 ${ }^{\mathrm{T}}, M$. barkeri $\mathrm{MS}^{\mathrm{T}}$, 227-BM, 227-Bes ${ }^{\mathrm{r}}$, Jülich, 227, S-3, Wiesmor, Fusaro, 3, and FR-1, and $M$. vacuolata Z-761 ${ }^{\mathrm{T}}$. (B) Molecular weight standards, $M$. acetivorans $\mathrm{C}_{2 \mathrm{~A}^{\mathrm{T}}}, M$. vacuolata $\mathrm{Z}-761^{\mathrm{T}}, M$. barkeri $\mathrm{MS}^{\mathrm{T}}$, and $M$. mazei S-6 ${ }^{\mathrm{T}}$, Equi, GA3, GA4, GA5, GA6, GA8, GA12, GA14, and GA15. (C) Molecular weight standards, $M$. acetivorans $\mathrm{C}^{2} \mathrm{~A}^{\mathrm{T}}, M$. vacuolata Z-761 ${ }^{\mathrm{T}}$, M. barkeri MS ${ }^{\mathrm{T}}$, and $M$. mazei S-6 ${ }^{\mathrm{T}}$, UBS, C 16, LYC, CW3A, Gö1, G1, KCl-2S, MCMB703, and Z-558. 


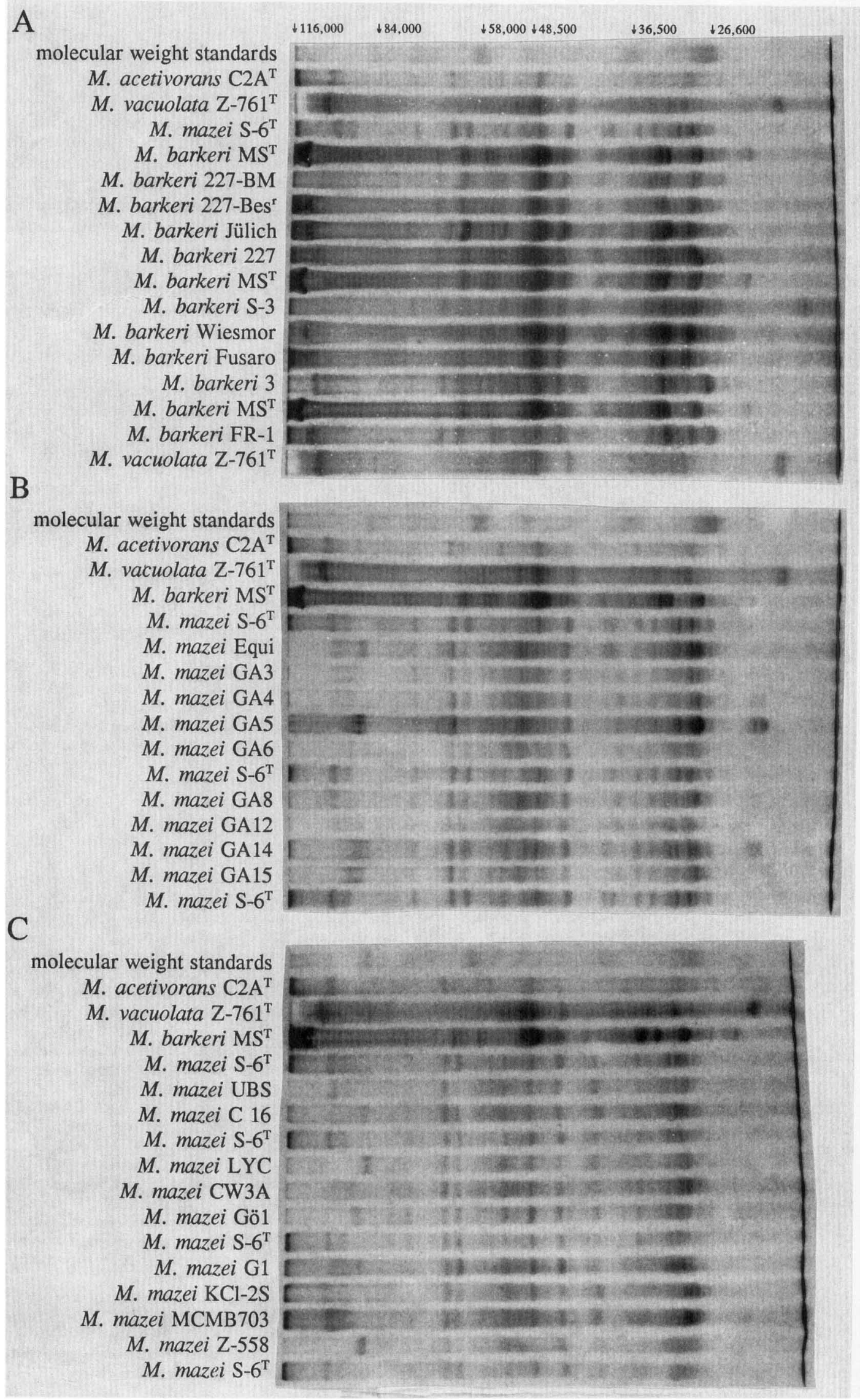



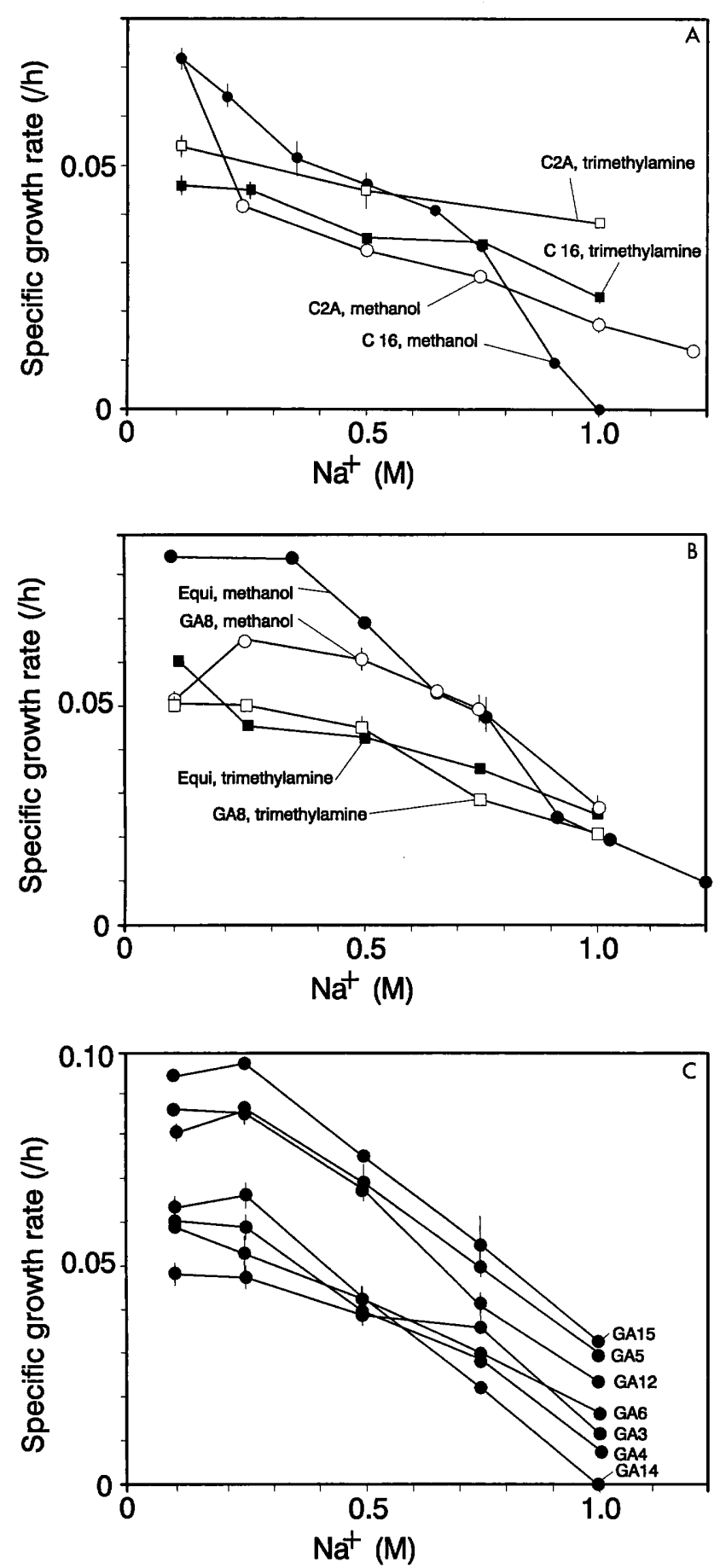

FIG. 2. Influence of salinity on the specific growth rates of Methanosarcina strains grown on methanol or on trimethylamine. The growth substrate was methanol unless indicated otherwise. The standard deviation for each data point is indicated by a vertical bar; the data points without vertical bars had standard deviations that were smaller than the sizes of the symbols.

The proteins of $M$. vacuolata $\mathrm{Z}-761^{\mathrm{T}}$ and $M$. acetivorans $\mathrm{C} 2 \mathrm{~A}^{\mathrm{t}}$ were clearly different, which should allow accurate assignment of gas vesicle-containing Methanosarcina strains to the appropriate species in the future. Assignment of reference strains is important taxonomically because it al- lows workers to determine whether characteristics are rare or common among members of a species. The taxonomy of many methanogenic species is hampered by the lack of reference strains, and many descriptions are based on a single isolate. For the Methanosarcina species included in this study, denaturing electrophoresis of whole-cell proteins is an easy, rapid method for assigning strains to species.

When cells are prepared for electrophoresis, incomplete breakage may lead to low yields and anomolous results. Methanosarcina cells are often particularly difficult to break, but we found that vortexing the cells with glass beads readily broke $M$. vacuolata cells.

Habitat of $M$. mazei. The habitats of reference strains of $M$. mazei now include anaerobic digestors, marine and freshwater sediments, and the gastrointestinal tracts of animals.

\section{ACKNOWLEDGMENTS}

We thank Mary Taylor (Portland State University) for help in disrupting cells and Jim Cregg (Oregon Graduate Institute) for helpful discussions and suggestions.

This work was supported by grants $480-323-4023$ and IFAS-GRIFIA-MCS 2171 from the Gas Research Institute as part of the Program on Methane from Biomass in collaboration with the Institute of Food and Agricultural Sciences, University of Florida, and by the Consejo Superior de Investigaciones Científicas, Madrid, Spain.

\section{REFERENCES}

1. Archer, D. B., and N. R. King. 1983. A novel ultrastructural feature of a vacuolated Methanosarcina. FEMS Microbiol. Lett. 16:217-223.

2. Balch, W. E., G. E. Fox, L. J. Magrum, C. R. Woese, and R. S. Wolfe. 1979. Methanogens: reevaluation of a unique physiological group. Microbiol. Rev. 43:260-296.

3. Blotevogel, K.-H., and U. Fischer. 1989. Transfer of Methanococcus frisius to the genus Methanosarcina as Methanosarcina frisia comb. nov. Int. J. Syst. Bacteriol. 39:91-92.

4. Blotevogel, K.-H., U. Fischer, and K. H. Lüpkes. 1986. Methanococcus frisius sp. nov., a new methylotrophic marine methanogen. Can. J. Microbiol. 32:127-131.

5. Blotevogel, K.-H., and A. J. L. Macario. 1989. Antigenic relationship of Methanococcus frisius. Syst. Appl. Microbiol. 11: 148-150.

6. Boone, D. R., R. L. Johnson, and Y. Liu. 1989. Diffusion of the interspecies electron carriers $\mathrm{H}_{2}$ and formate in methanogenic ecosystems and its implications in the measurement of $K_{m}$ for $\mathrm{H}_{2}$ or formate uptake. Appl. Environ. Microbiol. 55:1735-1741.

7. Boone, D. R., J. A. G. F. Menaia, J. E. Boone, and R. A. Mah. 1987. Effects of hydrogen pressure during growth and effects of pregrowth with hydrogen on acetate degradation by Methanosarcina species. Appl. Environ. Microbiol. 53:83-87.

8. Boone, D. R., and W. B. Whitman. 1988. Proposal of minimal standards for describing new taxa of methanogenic bacteria. Int. J. Syst. Bacteriol. 38:212-219.

9. Bryant, M. P., and D. R. Boone. 1987. Emended description of strain $\mathrm{MS}^{\mathrm{T}}$ (= DSM $800^{\mathrm{T}}$ ), the type strain of Methanosarcina barkeri. Int. J. Syst. Bacteriol. 37:169-170.

10. Daniels, L., G. Fuchs, R. K. Thauer, and J. G. Zeikus. 1977. Carbon monoxide oxidation by methanogenic bacteria. J. Bacteriol. 132:118-126.

11. Deppenmeier, V., M. Blaut, A. Jussofie, and G. Gottschalk. 1988. A methyl-coM methylreductase system from methanogenic bacterium strain Gö1 not requiring ATP for activity. FEBS Lett. 241:60-64.

12. Deutsche Sammlung von Mikroorganismen. 1983. Catalog of strains. Deutsche Sammlung von Mikroorganismen, Braunschweig, Germany.

13. Deutsche Sammlung von Mikroorganismen. 1989. Catalog of strains. Deutsche Sammlung von Mikroorganismen, Braunschweig, Germany. 
14. Ferguson, T. L. 1982. Ph.D. thesis. University of California, Los Angeles.

15. Hungate, R. E. 1969. A roll tube method for cultivation of strict anaerobes. Methods Microbiol. 3B:117-132.

16. Johnson, J. L. 1985. DNA reassociation and RNA hybridization of bacterial nucleic acids. Methods Microbiol. 18:33-76.

17. Kandler, O., and H. Hippe. 1977. Lack of peptidoglycan in the cell walls of Methanosarcina barkeri. Arch. Microbiol. 113:5760.

18. Liu, Y., D. R. Boone, and C. Choy. 1990. Methanohalophilus oregonense sp. nov., a methylotrophic methanogen from an alkaline, saline aquifer. Int. J. Syst. Bacteriol. 40:111-116.

19. Liu, Y., D. R. Boone, R. Sleat, and R. A. Mah. 1985. Methanosarcina mazei LYC, a new methanogenic isolate which produces a disaggregating enzyme. Appl. Environ. Microbiol. 49:608-613.

20. Lysenko, A. M., and T. N. Zhilina. 1985. Taxonomic position of Methanosarcina vacuolata and Methanococcus halophilus determined by the technique of DNA-DNA hybridization. Mikrobiologiya 54:501-502.

21. Maestrojuán, G. M., and D. R. Boone. 1991. Characterization of Methanosarcina barkeri $\mathrm{MS}^{\mathrm{T}}$ and 227, Methanosarcina mazei S-6 ${ }^{\mathrm{T}}$, and Methanosarcina vacuolata $\mathrm{Z}-761^{\mathrm{T}}$. Int. J. Syst. Bacteriol. 41:267-274.

22. Maestrojuán, G. M., D. R. Boone, L. Zhang, and R. A. Mah. 1990. Transfer of Methanogenium bourgense, Methanogenium marisnigri, Methanogenium olentangyi, and Methanogenium thermophilicum to the genus Methanoculleus gen. nov., emendation of Methanoculleus marisnigri and Methanogenium, and description of a new strain of Methanoculleus marisnigri. Int. J. Syst. Bacteriol. 40:117-122.

23. Mah, R. A. 1980. Isolation and characterization of Methanococcus mazei. Curr. Microbiol. 3:321-326.

24. Mah, R. A., and D. R. Boone. 1987. Methanosarcina, p. 2198-2205. In J. T. Staley, N. Pfennig, R. G. E. Murray, and J. G. Holt (ed.), Bergey's manual of systematic bacteriology, vol. 3. The Williams \& Wilkins Co., Baltimore.

25. Mah, R. A., and D. A. Kuhn. 1984. Transfer of the type species of the genus Methanococcus to the genus Methanosarcina, naming it Methanosarcina mazei (Barker 1936) comb. nov. et emend. and conservation of the genus Methanococcus (Approved Lists 1980) with Methanococcus vannielii (Approved Lists 1980) as the type species. Int. J. Syst. Bacteriol. 34:263265.

26. Mah, R. A., M. R. Smith, and L. Baresi. 1978. Studies on an acetate-fermenting strain of Methanosarcina. Appl. Environ. Microbiol. 35:1174-1184.

27. Mayerhofer, L. E., A. J. L. Macario, and E. Conway de Macario. 1992. Lamina, a novel multicellular form of Methanosarcina mazei S-6. J. Bacteriol. 174:309-314.

28. McInerney, M. J., R. I. Mackie, and M. P. Bryant. 1981. Syntrophic association of a butyrate-degrading bacterium and methanosarcina enriched from bovine rumen fluid. Appl. Environ. Microbiol. 41:826-828.

29. Oakley, C. E., C. F. Weil, P. L. Kretz, and B. R. Oakley. 1987. Cloning of the riboB locus of Aspergillus nidulans. Gene 53:293298.

30. Oregon Collection of Methanogens. 1990. Catalog of strains. Oregon Graduate Institute, Beaverton.

31. Powell, G. E. 1983. Interpreting gas kinetics of batch cultures. Biotechnol. Lett. 5:437-440.
32. Ranade, D. R., P. C. Kadam, and S. H. Godbole. 1989. Methanogens from aquatic sediments in India, p. 154. In 5th International Symposium on Microbial Ecology, Kyoto, Japan.

33. Rouvière, P. E., and R. S. Wolfe. 1987. Use of subunits of the methylreductase protein for taxonomy of methanogenic bacteria. Arch. Microbiol. 148:253-259.

34. Scherer, P. A., and H. P. Bochem. 1983. Ultrastructural investigation of 12 Methanosarcina and related species grown on methanol for occurrence of polyphosphatelike inclusions. Can. J. Microbiol. 29:1190-1199.

35. Scherer, P. A., H. P. Bochem, J. D. Davis, and D. C. White. 1985. Flocculation in methanogens, a comparative study of Methanosarcina barkeri strains Jülich and Fusaro. Can. J. Microbiol. 32:137-144.

36. Schnellen, C. G. T. P. 1947 . Onderzekingen over de methaanginsting. Ph.D. thesis. Technisches Hoogeschool Delft, Druckkerij "De Maastad," Rotterdam, The Netherlands.

37. Smith, M. R., and R. A. Mah. 1981. 2-Bromoethanesulfonate: a selective agent for isolating resistant methanosarcina mutants. Curr. Microbiol. 6:321-326.

38. Smith, P. H. 1966. The microbial ecology of sludge methanogenesis. Dev. Ind. Microbiol. 7:155-161.

39. Sowers, K. R., S. F. Baron, and J. G. Ferry. 1984. Methanosarcina acetivorans sp. nov., an acetotrophic methane-producing bacterium isolated from marine sediments. Appl. Environ. Microbiol. 47:971-978.

40. Sowers, K. R., and R. P. Gunsalus. 1988. Adaptation for growth at various saline concentrations by the archaebacterium Methanosarcina thermophila. J. Bacteriol. 170:998-1002.

41. Sowers, K. R., J. L. Johnson, and J. G. Ferry. 1984. Phylogenetic relationships among the methylotrophic methane-producing bacteria and emendation of the family Methanosarcinaceae. Int. J. Syst. Bacteriol. 34:444-450.

42. Stadtman, T. C., and H. A. Barker. 1951. Studies on the methane fermentation. IX. The origin of methane in the acetate and methanol fermentations by Methanosarcina. J. Bacteriol. 61:81-86.

43. Summerton, J., T. Atkins, and R. Bestwick. 1983. A rapid method for preparation of bacterial plasmids. Anal. Biochem. 133:79-84.

44. Thomas, I., D. Verrier, H. C. Dubourguier, H. Hanoune, and C. Langrand. 1986. Numerical analysis of whole-cell protein patterns of methanogens, p. 245-253. In H. C. Dubourguier, G. Albagnac, J. Montreuil, C. Romond, P. Sautière, and J. Guillaume (ed.), Biology of anaerobic bacteria. Elsevier Science Publishers B. V., Amsterdam.

45. Weimer, P. J., and J. G. Zeikus. 1978. Acetate metabolism in Methanosarcina barkeri. Arch. Microbiol. 119:175-182.

46. Xun, L., D. R. Boone, and R. A. Mah. 1988. Control of the life cycle of Methanosarcina mazei S-6 by manipulation of growth conditions. Appl. Environ. Microbiol. 54:2064-2068.

47. Zhilina, T. N. 1978. Growth of a pure Methanosarcina culture, biotype 2, on acetate. Mikrobiologiya 47:321-323.

48. Zhilina, T. N., and G. A. Zavarzin. 1979. Cyst formation by Methanosarcina. Mikrobiologiya 48:349-354.

49. Zhilina, T. N., and G. A. Zavarzin. 1987. Methanosarcina vacuolata sp. nov., a vacuolated methanosarcina. Int. J. Syst. Bacteriol. 37:281-283.

50. Zhilina, T. N., and G. A. Zavarzin. 1989. Comparative cytology of Methanosarcinaceae and description of Methanosarcina vacuolata sp. nov. Mikrobiologiya 48:451-458. 